\title{
Shopping centres in the Warsaw Metropolitan Area
}

\author{
SYLWIA DUDEK-MAŃKOWSKA, Ph.D.
}

University of Warsaw, Faculty of Geography and Regional Studies,

Department of Urban Geography and Spatial Management

\begin{abstract}
The aim of the paper is a characterisation of shopping centres in the Warsaw Metropolitan Area. Types, distribution, and functions of the centres have been analysed. Next, the results of surveys conducted among residents of the capital city and concerning purposes and frequency of visits to the centres are presented. The Warsaw Metropolitan Area (WMA) has been chosen for the study because it is the area with the greatest saturation with shopping centres in Poland.
\end{abstract}

Keywords: Warsaw, Warsaw Metropolitan Area, shopping centre

\section{Introduction}

Contemporary shopping centres are complex and planned spaces whose purpose is to fulfil several varied functions. Modern shopping centres have retail and entertainment functions, but more and more often they offer also entertainment, recreational, cultural, integrational, social, housing, administrative, educational, and religious functions. Retail and entertainment complexes become also tourist attractions. According to Goeldner, Ritchie and McIntosh (2000), the Dade County's shopping centre in Miami, Florida, is one of the five most frequently visited places in Florida.

Shopping centres attract customers by their rich retail and catering offer, opportunities to spend leisure time, as well as by their size itself (total area) and sophisticated architectural form. Due to the rich entertainment offer, the line between this type of place and an entertainment park becomes blurred. Modern shopping centres accommodate cinemas, theatres, concert and exhibition halls, playgrounds, ice-skating rinks (often of Olympic size), bowling alleys, golf courses, ski lifts, artificial lakes, huge oceanaria.

Contemporary shopping centres are localised in various parts of the city; this is influenced mainly by their functions and the period of construction. Certain tendencies in the localisation of shopping centres can be namely distinguished. An interesting example is provided by Great Britain, where three approaches to the choice of localisation of large shopping centres are distinguished (Lowe 2000). In 1960s and 
1970s, shopping centres had been built mainly in town and city centres (e.g. Arndale Centre in Manchester; Eldon Square in Newcastle). In 1980, such facilities had been built in suburbs. At that time, large shopping and leisure centres modelled after American shopping malls were being built (e.g. Metrocentre in Gateshead; Meadowhall in Sheffield). The change in localisation of shopping centres in Great Britain occurred in 1990s, when shopping centres returned to city centres and were part of the plans of regeneration of neglected central neighbourhoods (e.g. West Quay in Southampton).

The layout of most shopping centres suggests the layout of a town. In fact, shopping centres are supposed to imitate town centres, and, in addition, to isolate the customer from the external world. They are supposed to be a more attractive alternative to public spaces, attracting visitors by higher safety level and greater convenience in the use of services offered.

The objective of the paper is a characteristic of shopping centres located in the WMA. Types, distribution, and functions of shopping centres have been analysed.

\section{Shopping centre - definition and classification}

Shopping centres - multi-functional facilities, as was previously noted - are undoubtedly among the most modern form of retail. However, various facilities are referred to as shopping centres - differentiated as regards both their size and the variety of services provided. In the literature of the subject we encounter various definitions of a shopping centre. The most often cited definition, that by R. J. McKeever, states that a shopping centre is a group of shops planned, constructed, and managed as a single object, connected by their localisation, size (total retail space) and the type of shops with the area of influence of the entire facility; with a car parking separated from the street and located on the same land lot (Wilk 2003). A very similar definition is that provided by the International Council of Shopping Centres (ICSC) which is more often used by researchers. This definition has been created on the basis of research conducted by ICSC in 2005 in several European countries. The creation of the definition had as objective to facilitate research involving comparison of these facilities on international scale. According to ICSC, a European shopping centre is a retail property that is planned, built and managed as a single entity, comprising units and "communal" areas with a minimum gross leasable area (GLA) of 5,000 $\mathrm{m}^{2}$ (ICSC 2005) Various classifications of shopping centres can also be encountered in the literature, but most of them are based on the same criteria, that is: size (total area, retail area), number of shops, range of influence of the complex. In this paper the classification created by ICSC, based on analysis of shopping centres in Europe is used. Ten international types of shopping centres have been proposed, grouped into two categories: traditional and specialised shopping centres (Fig. 1). The main difference between the focused and the traditional shopping centres consists in specific tenant mix. While a traditional shopping centre, regardless of its size, usually features a supermarket or hypermarket and a gallery of shops representing various industries, a retail park is mainly a collection of mid- and large specialised shops, a factory outlet centre is a collection 
of manufacturers' shops selling their own brands at a discount, and in a theme-oriented centre, retailers focus on a narrow category of goods sold (ICSC 2005).

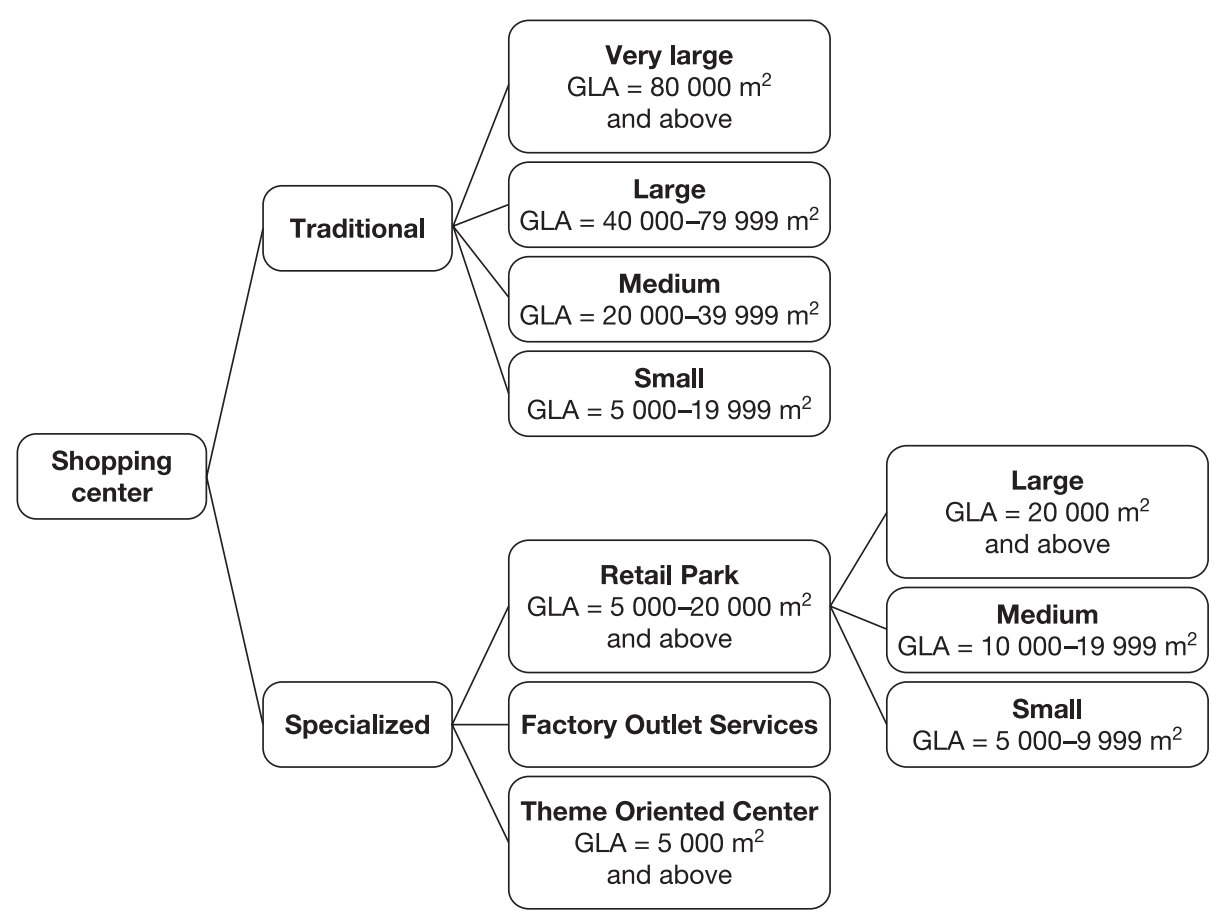

Figure 1 Types of shopping centres

Sources: International Council of Shopping Centres (2005)

\section{Shopping centres - new spaces in the WMA}

Shopping centres have existed in the space of Polish cities since the mid-1990s, while in the USA they have operated since the 1950s and in Western Europe, since 1960s (Wilk 2003).

In Poland globalization trends can be notice after 1989. The systemic changes in Poland were revolutionary and reached the structure of the basic subsystem of the state: political, social and economic. Effects of the transformation had the bigger impact on situation in cities than in the country. Polish cities have become attractive localisation for foreign investments. Many global firms have entered the Polish market. Some investment was made in a few fields in Poland such as new form of trade. Foreign investment brang to Poland supermarkets and shopping centres. New investments have largely concentrated in the biggest cities, especially Warsaw (Parysek 2004). 
The first hypermarket in WMA, and also in the entire Poland, was Auchan at Puławska Street in Piaseczno (opened in 1996), while the first shopping centre was King Cross Praga (opened in 1996). During the next ten years, significant changes occurred in Warsaw, as regards the size of the retail establishments, their architecture and also their function. A large part of retail spaces existing today in Warsaw was put into operation during two years, that is, in 1998 and 1999. Shopping centres operating in the WMA belong to various types. The largest group consists of traditional shopping centres, classified as medium and small due to their area; but large and very large centres also exist in the WMA. Specialised centres, on the other hand, occur definitely less frequently. One can distinguish four retail parks and two factory outlet centres. There are no theme parks in Warsaw, however.

The first shopping centres built in the WMA can be classified as first- and secondgeneration centres. In first-generation centres the most important shop (anchor) was a supermarket or a hypermarket, making up approx. 60-70\% of the total area of the entire centre. This was supplemented by a medium size gallery. To this type belong such shopping centres built in the 1990s as Hit (Górczewska St and KEN St), Auchan (Puławska St and Modlińska St), Leclerc (Ciszewski St).

The next stage in the development of shopping centres was the introduction of large establishments, with the retail gallery making up approx. $70 \%$ of the total area. Such centres are called second-generation centres; to this category belong, for instance, M1 Centre, Reduta, Klif and Wileńska Gallery.

The last stage in the development of Warsaw's shopping centres was the construction of complexes with a large gallery whose area constitutes approx. $70 \%$ of the total area, and with a wide range of entertainment services. Visitors to such centres can not only do their basic shopping or use catering facilities - as in firstand second-generation centres - but spend their leisure time, too. Eight such centres operate in Warsaw and one in the Nadarzyn gmina (CH Janki). The Warsaw centres of third generation are: Galeria Mokotów (the first third-generation centre in Warsaw, opened in 1999), Sadyba Best Mall, Arkadia, Blue City, Promenada, Targówek, Wola Park and Złote Tarasy (Golden Terraces). The last one, opened in 2007, due to the localisation of office space within it, is classified as one of two complexes of fourth generation in Poland. The other fourth-generation centre in Poland is Manufaktura in Łódź.

Specialised shopping centres began to be built in Warsaw much later. Retail parks were being built along the thoroughfares leading out of Warsaw. Inter Ikea opened the first two retail parks: in the Targówek district (2006) and in Janki near Warsaw (2004). The next centre of this type - in the vicinity of the Okęcie airport - was built in 2002 and was being expanded during the next three years. The most recently built retail park in Warsaw is Zielony Park Handlowy (Green Retail Park) localised in the neighbourhood of the Shopping Centre Targówek.

Similarly, outlet centres are localised outside the city centre. The first such complex, Factory Outlet, opened in 2002, has been localised in a post-industrial district of the Ursus suburb. A second complex, Fashion House, opened in 2005, is localised in the town of Piaseczno, near a thoroughfare leading out of Warsaw. 
An analysis of the distribution of shopping centres in Warsaw and its suburbs shows that large shopping centres are present in various places in Warsaw and in some gminas surrounding the city (Fig. 2). The vast majority of them have been built in the parts of Warsaw on the left bank of the Vistula river. Most of the traditional shopping centres and retail parks, as well as all the outlet centres are here. The vast majority of the shopping centres described is localised in Warsaw. First- and second-generation shopping centres have a relatively small zone of influence. Most of them are small- and medium centres. They are classified as focus centres and built outside the city centre, mostly in suburbs and in the neighbouring gminas. In four city district, however, no shopping centre has been built (Rembertów, Wawer, Wilanów and Wesoła).

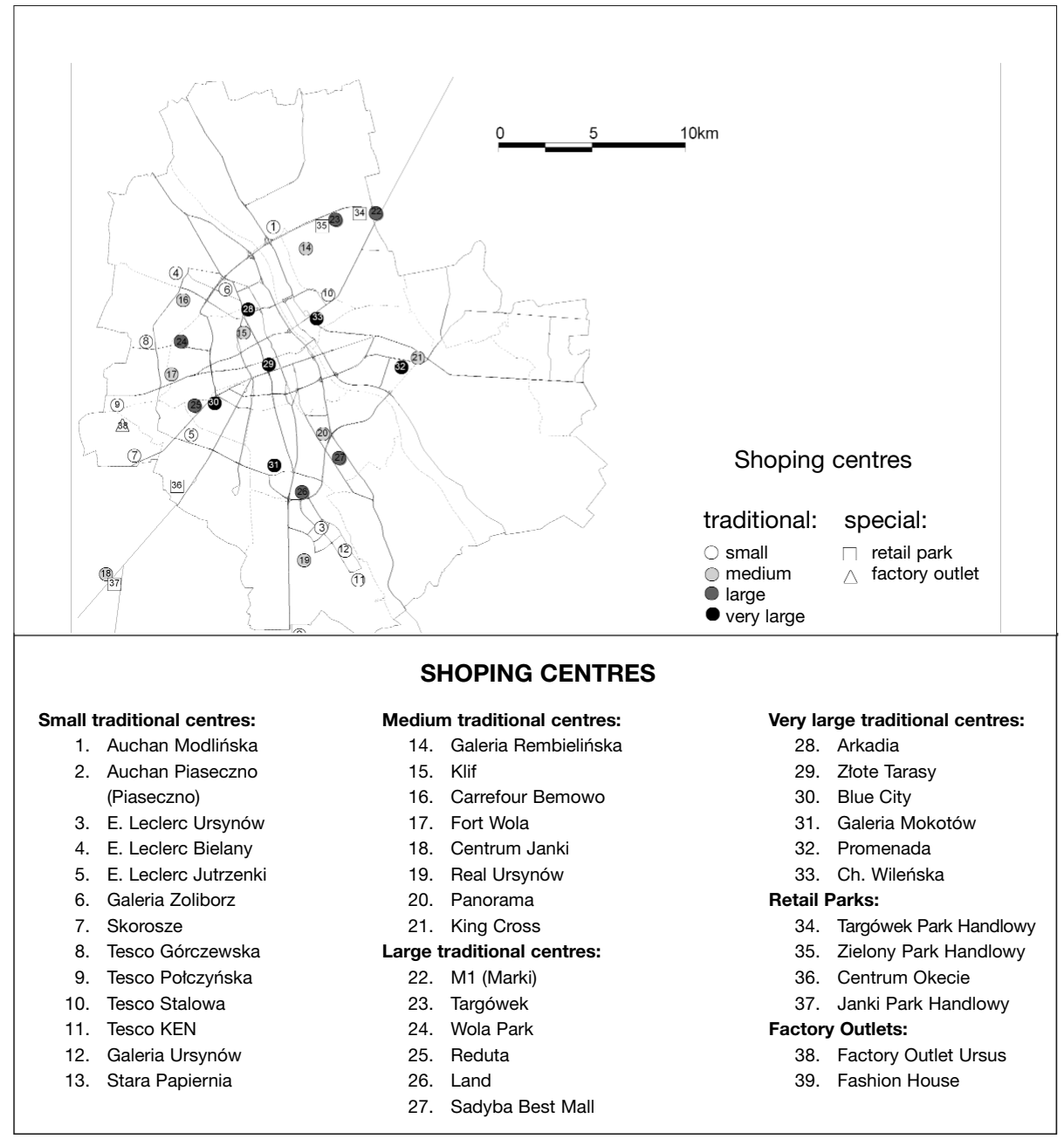

Figure 2 Shopping centres in Warsaw Metropolitan Area Author's own study 
Third- and fourth-generation shopping centres are present in various parts of the city. Most of them have regional or even larger zone of influence and are easily accessible by various modes of transport. They are located in the city centre or next to the main thoroughfares. Two of Warsaw shopping centres are in the vicinity of railway stations (Złote Tarasy, Arkadia).

Worth noting is a large accumulation of retail facilities in two areas: in Janki and at the boundary between the Marki gmina and the Targówek district. In Janki, as we have already mentioned, there is a shopping centre of third generation ( $\mathrm{CH}$ Janki) with a hypermarket, a cinema, a consumer electronics store (Saturn) and a home improvement hypermarket (Leroy Merlin). The retail park Janki - a specialised furniture and interior furnishing centre is also localised in the vicinity. The shopping centre was opened in 1995, while the retail park has been in operation since 2004. The retail area of the park is $52,000 \mathrm{~m}^{2}$. The park consists of 40 retailers, including a large consumer electronics store (Electro World), a home improvement hypermarket (Praktiker) and an IKEA store. There are also service facilities, such as dry cleaning service, travel agency, banks, pharmacy, beauty parlour, flower shop, post office, car wash and petrol station.

The second place with an accumulation of large shopping centres is located in north-east of Warsaw. A second-generation shopping centre is located there (M1 with the Real supermarket). In the nearest neighbourhood is Poland's largest supra-regional interior furnishing centre consisting of approx. 100 shops and several buildings - the Targówek Retail Park. The centre is constantly being expanded. The target retail space is $118,500 \mathrm{~m}^{2}$. The first stores, IKEA and Decathlon, were opened in 2001, while the next facility, a consumer electronics store (Electro World) opened in 2005. The retail park was opened in 2006. The park accommodates, among other facilities, the home improvement hypermarket Leroy Merlin, and next to it, a golf course.

Not far from it are other shopping centres: $\mathrm{CH}$ Targówek, Zielony Park Handlowy (Green Retail Park), the home improvement and DIY shop Castorama and a petrol station. The Targówek Retail Park is connected with them by a road constructed for this purpose.

In the Warsaw suburban zone there are five shopping centres of various types. Two of them are first-generation centres (Stara Papiernia in Konstancin-Jeziorna, Auchan Piaseczno), two are second-generation centres (M1 in Marki, Centrum Janki in Raszyn), one is a retail park (Janki Park Handlowy in Raszyn) and one a factory outlet centre (Fashion House in Piaseczno). A retail and entertainment centre (Galeria Otwock) is under construction; two more complexes are planned (Auchan Łomianki, HeadLand Shopping Centre in Piaseczno).

In 200833 modern shopping centres were in operation in the WMA, with the total leasable area of 1,046,000 $\mathrm{m}^{2}$ (Jones Lang LaSalle 2008). Therefore the saturation with area reached $496 \mathrm{~m}^{2}$ per 1000 inhabitants, putting the WMA at the third place among the eight largest agglomerations in Poland.

One should add that the rate of increase of modern retail space in Warsaw has slowed down in the recent years. Year 2007 brought 76,000 $\mathrm{m}^{2}$ of new space in shopping centres, while in 2008 only one fairly small centre with the area 13,000 $\mathrm{m}^{2}$ was opened. This complex, Galeria Rembielińska, exemplifies a popular trend of integrating a shopping centre with a housing complex (Jones Lang LaSalle 2008). 
Compared with other cities, Warsaw is also distinguished by the structure of its shopping centres. Most of them are modern retail and entertainment centres, while in other cities, retail and service centres dominate (Fig. 3).

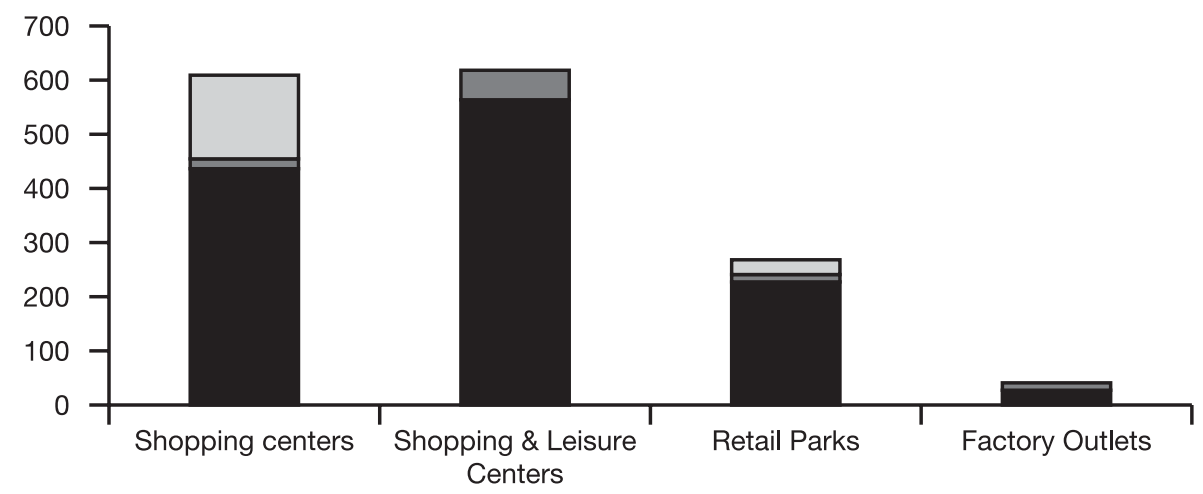

- Existing $\quad \square$ Under construction $\quad \square$ Planned

Figure 3 Retail Formats in Warsaw Metropolitan Area

Sources: developed on the basis of Jones Lang LaSalle (2008)

\section{Functions of selected Warsaw shopping centres}

Contemporary shopping centres have more and more functions. They are called centres (retail and service centres, retail and entertainment centres) for a good reason, since they are places of exchange of goods and services, just as traditional city or town centres have been in the past. Often, spending leisure time in modern commercial spaces is much more attractive for people than in the public space of a city.

Modern shopping complexes in the WMA can be divided into two basic groups: retail and service centres (shopping centres of first and second generations) and retail and entertainment centres (shopping centres of third and fourth generations).

Traditional retail and service centres can be divided into two types. The first type is distinguished by the presence - apart from several small shops and service facilities of a hypermarket playing the role of an anchor. Its role is to attract task-oriented customers who intend to do their shopping quickly and comprehensively. Usually, the anchor is located sufficiently far from all the entrances for the customers to pass by at least a few shops and, as a result, to remain in the centre longer that they intended to (Makowski 2004). This type of shopping centre is exemplified by: $\mathrm{CH}$ Bemowo, $\mathrm{CH}$ Reduta or CH Wileńska.

The second type is represented by one shopping centre only, the Mokotów Land. This centre accommodates only retail and service facilities located in a multi-storey gallery.

The second group of retail centres are retail and entertainment centres. These facilities are characterised by an entertainment component, playing the role of an 
anchor and attracting visitors who want to spend their leisure time in the centre; there are also retail and service facilities and a food court. Such centres can be divided into two types. In type 1 facilities, both the entertainment component and the large retail space act as anchors, while in type 2 facilities only the entertainment component is the anchor. Examples of these two types are: of type 1, Arkadia and Wola Park; of type 2, Blue City and Promenada.

To determine the functions of contemporary shopping centres which can be found in the Warsaw centres, types of facilities localised in the centres have been investigated. The analysis is limited to retail and entertainment centres, since they are the most modern shopping centres with functions exceeding those of retail.

The most important function of the retail and entertainment centres is undoubtedly retail. In modern shopping centres of the WMA there are very many shops with all kinds of assortment (Fig. 4). The largest group of shops - dominating in all the centres - consists of clothing and footwear shops. The accumulation of fashionable shops and brand shops makes them into places where people come to find out the fashion for the given season. In every shopping centre there are also food shops, sports shops, furniture shops, consumer electronic shops, perfume shops, pet shops and bookshops.

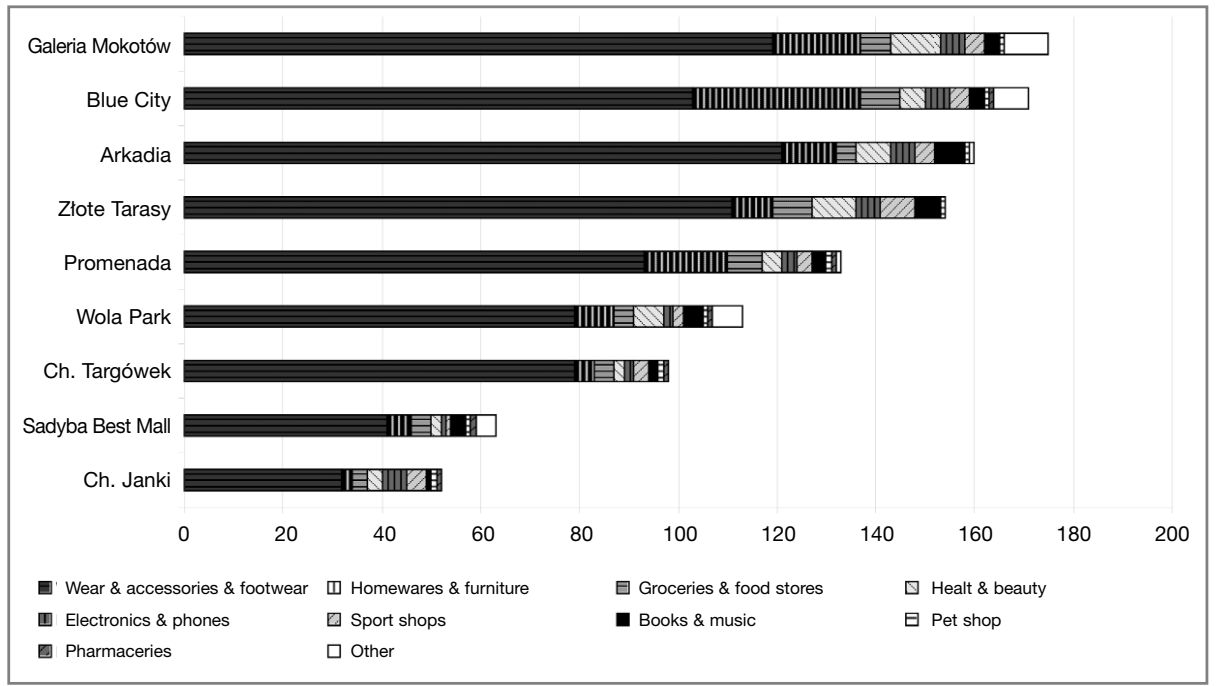

Figure 4 Retail facilities in WMA retail and entertainment centers Author's own study

An interesting example is Blue City, which houses several furniture shops. For this type of merchandise a separate floor of the gallery is devoted, called Home City.

The retail and entertainment centres described here accommodate also very many service and catering facilities (Fig. 5). Most of them, in all the centres, are restaurants, cafés and bars. Everywhere there are also hairdressers, banks, photo services, travel 
agencies, dry-cleaning services, key duplication services, flower shops. Worth noting is also the presence of hospitals - Enel Med in Blue City and in Arkadia.

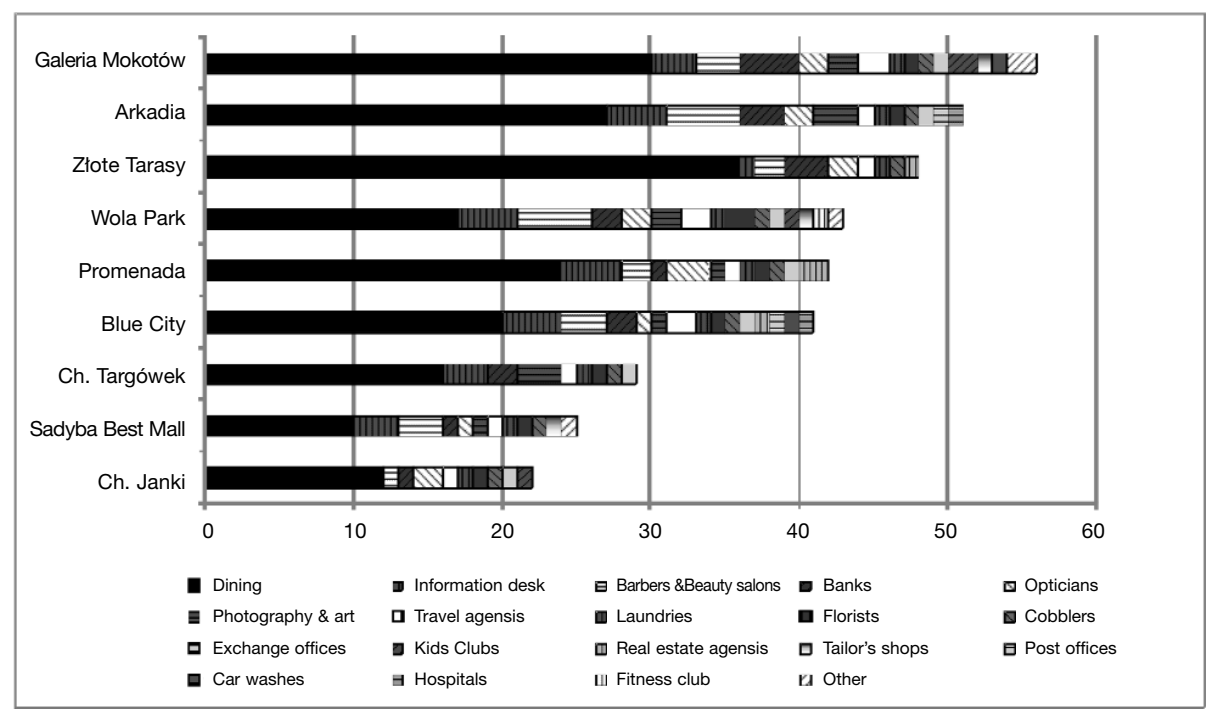

Figure 5 Service facilities in WMA retail and entertainment centers Author's own study

The next function of retail and entertainment centres in the WMA is entertainment. There are few entertainment facilities in the centres, although the existing ones have a large share in the total area of the entire centre. The largest number of entertainment facilities features Blue City. The centre includes Magic City (a miniature amusement park for children, an amusement park for the whole family and a discotheque). In all the other centres multiplex cinemas have the entertainment function. An extremely important entertainment function has also the cinema in Janki, the most modern movie theatre in the Warsaw suburban zone, which also attracts the largest number of viewers.

Retail and entertainment centres, with the exception of Arkadia and $\mathrm{CH}$ Targówek, have also recreational function. In Blue City the residents of Warsaw can use a go-cart track and Skate Park; in the Wola Park, they can use the "sport park" (volleyball and basketball courts, ice-skating rink), and a fitness club. One of the most important attractions of the Promenada is an indoor ice-skating rink, and of Galeria Mokotów and Sadyba Best Mall, bowling alleys. The recreational facilities are among the most important places that attract visitors to shopping centres, which may be a result, perhaps, of the scarcity of such offers in the city.

Retail and entertainment centres are also cultural centres: exhibitions, shows, concerts, and meetings with artists are organised there.

One should not forget the integration function, either. The restaurants and cafés in the centres are meeting places. The character of these facilities does not differ from that of catering facilities outside the centres. Another important place in every 
modern shopping centre is a central plaza whose function is similar to that of town squares.

One can therefore say that as regards their functions, the Warsaw retail and entertainment centres are retail complexes of the newest generation, which can compete with the traditional city centres.

\section{Shopping centres versus city centres - opinions of inhabitants ${ }^{1}$}

Analysis of the current situation in Poland shows that city communities turn their back to the city centre. This is undoubtedly related to the crisis of the city centres, which are often declining and unsafe, and are not able to fill many of the population's needs. Shopping centres compete with public spaces mainly by means of their functions, but also with their architecture, interior and atmosphere. Modern shopping facilities become miniature cities, and that is why the walkways in modern shopping centres refer to city alleys and in the central points of the centres there are small piazzas functioning similarly to town squares. Analogously as in towns and cities, elements of street furniture (benches, kiosks or fountains) and signage are distributed throughout the centres.

Surveys conducted among the residents confirmed that those polled often visit shopping centres and make use of their offers. When asked about their favourite shopping place, over $80 \%$ of those polled indicated shopping centres, while only less than $10 \%$ mentioned shops located in the city centre. On the other hand, the residents of Warsaw spend their leisure time definitely more often in the city centre $-50 \%$ of those polled indicated facilities in the city centre, and only $20 \%$, retail and entertainment centres. One should however note that a significant part of people who indicated the city centre stressed that they very rarely make use of its offer. The population that does like to visit shopping centres in their leisure time consists mainly of young people who visit such places often and regularly. The residents of Warsaw often use services both in the city centre (44\% of those polled) and in the shopping centres $(38 \%)$. The choice of the place visited is related mainly to the kind of the given service.

The residents of Warsaw visit shopping centres often. Almost $80 \%$ of those polled visit the Warsaw shopping centres several times per month, and over $10 \%$, several times per week. Among those polled was also a group of young people who visit the shopping centres every day. The main purpose of the respondents' visit was shopping. Many of them said, however, that when coming to a shopping centre they don't have exact plans concerning purchases. Approx. one half of those polled indicated that they also enjoy getting together with friends or family in shopping centres. Usually, this is related to shopping together, although there is also a group of respondents who visit only cinemas or restaurants. The smallest number of visitors is those who visit

1 In the survey 457 respondents have been interviewed; it has been conducted in 31 randomly selected Warsaw secondary schools. 
shopping centres only to use their service facilities. Usually those polled indicated that they visit service facilities in shopping centres because they can combine such a visit with shopping, thereby saving their time.

The popularity of shopping centres among Warsaw residents is undoubtedly related to the poverty of offer of the city centre. In the opinion of those polled, the centre of Warsaw functions mostly as a place for retail and entertainment. They said, however, that the centre of Warsaw lacks shops with luxury brands; they are also not satisfied with the distribution of retail establishments in the centre and complain about the lack of elegant streets. They highly appraise the functioning of clubs or pubs in the city centre; in the context of these facilities they point out the entertainment function of the city centre. The percentage of those polled who list the recreational role of the city centre is small. In the opinion of the residents of Warsaw, the entire city, and above all the city centre, lacks facilities for active leisure activities.

The study conducted shows that in Warsaw, shopping centres compete with the city centre, and have very many functions - also those which in the opinion of those polled are poorly represented in the city centre. The residents visit modern shopping centres often; the offer of shopping centres is being expanded, thanks to which they become a more attractive alternative to public spaces.

\section{Conclusion}

Changes in retail market in Warsaw was connected with the socio-economic and spatial transformation. The share of capital invested in retail sector - primarily for large shopping centres has increased dramatically in all CEE countries (Stanilov 2007). According to the report "Shopping Centres in Central Europe", Poland and Romania will add the most substantial amount of shopping centre space in 2008-2009. Moreover Poland is the most developed country in terms of shopping centre GLA. In 2007 , it accounted for $50 \%$ of total shopping centre supply in the region, and was followed by the Czech Republic (16\%), Hungary (15\%), Romania (10\%), Slovakia $(7 \%)$ and Bulgaria $(2 \%)$.

Warsaw's retail sector is very interesting not only because of number of shopping centres but also their localisation. Warsaw is a city with many varied retail establishments. Over 15 years, in the WMA over 30 shopping centres of various types have been built. Among them there are specialised centres - retail parks, where furniture stores dominate, and outlet centres offering clothing of famous brands. There are also small and medium shopping centres which attract customers mostly with their super- or hypermarkets, as well as large and very large centres, attracting people from the entire region.

The distribution of such places in Warsaw is not uniform. Neighbourhood shopping centres are localised mostly in on the outskirts of Warsaw. Large shopping centres of third and fourth generations exist both in the city centre and along the thoroughfares leading out of Warsaw (also outside Warsaw). Retail parks and outlet centres are located on the outskirts of the city or outside the city boundaries. 
The vast majority of shopping centres is located in the districts on the left bank of the Vistula river. Four Warsaw districts still have no shopping centres.

The shopping centre market in the WMA certainly underwent a transformation in the recent years. It seems that it became already saturated with large and very large traditional shopping centres, including retail and entertainment centres. In recent years, a dynamic growth is exhibited by the market segment of retail parks which are constantly being expanded. Smaller (district) shopping centres are being created, often as parts of housing complexes. Also, the saturation with modern retail space in various city districts and also in the vicinity of Warsaw is strongly differentiated. Retail space market analysts foresee an inflow of investments to two dynamically growing Warsaw districts: Białołęka and Wilanów. The situation on the shopping centre market in the WMA can be changed also the financial crisis which affected Poland in 2008; among its symptoms were bankruptcies of several Polish clothing manufacturers. This can influence the tenant mix, as well as the profitability of the shopping centres themselves.

Shopping centres have very many functions: they are places of exchange of goods and services, but also meeting places. Residents of Warsaw visit them frequently. This can be a result, among other things, of their broad offer, easy access by various modes of transport, no dependence on weather conditions, convenient opening hours, attractive interior and safety provided by security personnel.

Shopping centres imitate city centres not only with their spatial layout and interior furnishing, but also with their functions. The study conducted shows that the centre of Warsaw is a chaotic and not very attractive place offering few amenities. The inhabitants point out that they expect further transformations of the centre of Warsaw so that it becomes a friendly place to which recreational and cultural functions will be introduced. Therefore, it apparently depends on the efforts of city authorities and their actions aiming at building a new central space for the city, whether in the future shopping centres will constitute an alternative to the city centre or only a complement of the city's offer.

\section{References}

GOELDNER, CH. R. J. R.; RITCHIE, B.; MCINTOSH, R. W. (2000): Tourism: principles, practices, philosophies. New York: John Wiley and Sons Inc.

LOWE, M. (2000): Britain's Regional Shopping Centres: New Urban Forms? Urban Studies 37 (2), 261-274.

MAKOWSKI, G. (2004): Świątynia konsumpcji: geneza i społeczne znacznie centrum handlowego [The temple of consumption: the origin and social significance of the shopping Centre] Trio. Warszawa.

One step closer to a Pan-European Shopping Center Standard (2005). ICSC. <http://www.icsc.org/srch /lib/euro_standard_only.pdf>

PARYSEK, J. (2004): The socio-economic and spatial transformation of Polish cities after 1989, Dela 21, 109-119.

Shopping centres in Central Europe (2008). PMR Publications.

STANILOV, K. (eds.) (2007): The restricting of non-residential uses in the post-socialist metropolis (73-100). Dordrecht. Springer.

Warsaw City Report. Year-end 2008 (2008). Jones Lang LaSalle. 
WILK, W. (2003): Między zakupami a rozrywką - nowe znaczenie centrum handlowego. [Between shopping and leisure - a new meaning of shopping centres]. Prace i Studia Geograficzne, 32, 205-224.

\section{Résumé}

\section{Nákupní centra v metropolitní oblasti Varšava}

Př́spěvek se věnuje charakteristice nákupních center ve Varšavě. Analyzovány jsou typy, distribuce a funkce jednotlivých center. Prezentovány jsou výsledky průzkumů mezi obyvateli hlavního města se zaměřením na smysl a frekvenci návštěvnosti center. Metropolitní oblast Varšava (WMA) byla vybrána z důvodu největší saturace nákupních středisek v Polsku.

Sylwia Dudek-Mańkowska, Ph.D.

Department of Urban Geography and Spatial Management Institute of Socio-Economic Geography and Spatial Management Faculty of Geography and Regional Studies, University of Warsaw Krakowskie Przedmieście 30 00-927 Warsaw tel.: (+ 48 22) 5521512 e-mail:s.mankowska@uw.edu.pl 